\section{THE ROYAL SOCIETY}

UR anniversary is in one sense the opening of a new year, in another it is the close of an old one. With one hand we weclome the coming, with the other we bid farewell to the departing guest. In the later parts of my present address I shall have to speak, as on former occassions, of our prospects and hopes for the future. At our more festive gathering in the evening we shall recount some of the victories which have been won over difficulties in the extension of knowledge, and shall rejoice at the gathering of old comrades and friends after our usual period of dispersion. But at the moment of taking my place in the chair to which you have now for the fourth time elected me, I must confess that the sadder side of the picture is the most prominent. We seem almost for the moment to enter the Valley of the Shadow of Death, or, like Dante, to descend to the place of Departed Spirits, and to commune with them once more after they have vanished from the upper world. Each year during my own term of office the numbers lost to us have been greater than the numbers gained; but this year, although the list of deaths is long and comprises not a few distinguished Fellows, they all seem overshadowed by two prominent figures. One of these died in the fulness of years, of honours, and of world-wide reputation; the other in the strength and bouyancy of youth, a buoyancy which appears to have even contributed to his end.

Of Darwin and his works it is not for me to speak. Others, with wider knowledge, after longer intercourse, and with greater authority, have said what was possible at the moment, and the full story of his life is now being written by faithful hands. But I consider it no common piece of fortune to have lived within easy distance of his house: to have been able by a short pilgrimage to enjoy his bright welcome, and his genial conversation, and to revive from time to time a mental picture of that my ideal of the philosophic life.

Of Balfour I knew far less, and his works "are beyond my range of knowledge. But such was the fascination of his speech and his demeanour that to have seen him was to desire to know him better. To have been selected at his age as one of the Secretaries of the British Association, a post usually reserved for men of more advanced years and of longer experience, to have been appointed to a professorship founded almost on the luasis of his own work, and thereby to have become the coadjutor of his own great master in the Physiological School at Cambridge and all this without one word of cavil or of criticism, was a high testimony to his scientific eminence. But far wider afield, it will be remembered of him, not so much that he was brilliant in intellect, or keen of insight, or varied in his attainments, but th it he always found himself among friends, whether in college or in the laboratory, in his own home over the northern border, or on the wild mountain side where he breathed his last.

The list of deceased Fellows comprises other eminent names, many of whom will receive mention in our obituary notices. The list, moreover, "serves again to exemplify the variety of qualifications which have opened our doors to election. In Decimus Burton we find an architect of refined taste and cultivated mind; in Stanley Jevons and William Newmarch statisticians of weight, and the former already an authority on political and other philosophy; in Sir Woodbine Parish a geographer, and more than a geographer, a man who by service as well as by study in foreign lands had acquired an unusual a mount of first hand and accurate information ; in Scott Russell an engineer whose brilliant early strokes of work will be remembered when the difficulties which entangled his later efforts have been long forgotten ; in Dr. Robinson a veteran and mentor in science, whose work and whose judgment were alike sound. Of Sir Wyville Thomson mention will be made elsewhere.

To this list of names there was well nigh added yet another, nameiy, my own. An accident, under circumstances which the issue of events and more mature reflection have shown that $I$ was hardly justified in incurring, has for some time past interfered materially with my usual avocations in life, and thereby, as I fear, with my usefulness to the Society. But the ready and efficient assistance of the other officers has, I doubt not, gone far to supply the deficiency. For myself, I am consoled by the kind expression of sympathy from many, some even anknown, friends ; and by the consideration, ever present to my mind, that, except through a combination of circumstances over which I had certainly no conscious control, the result to myself might have been far more serious.

Address of the President, William Spottiswoode, D.C.L., LL.D., delivered at the Anniversary Meeting, November 30, 1882.

The total number of Fellow's lost to our ranks during the past year is twenty-two on the home list (one of whom has withdrawn on account of growing infirmities), and four on the foreign list ; a result, on the whole, not very different from that of last year.

Of these two fell young, and by accident. Of the remainder, two died between the ages of 50 and 60 , four between those of 60 and 70 , six between those of 70 and 80 ; and the remaining five attained ages between four score and 90 .

In Liouvilie we have again lost a veteran mathematician; in Wöhler, a chemist whose years, numbered from the beginning of the present century, reached to a period almost prehistoric in the records of his science.

I am happy to report that the sale of the Acton estate has been completed ; and that of the proceeds, amounting to $32,250 l$., 17,000l. has been invested in preference or guaranteed railway stock; and the remainder will be expended in the purchase of ground rents, partly in the City of London, and partly in the western suburbs. The income from the latter source, already representing a very fair interest on the outlay, may be expected materially to increase at the expiration of the existing buildins leases. Some additional expense was incurred this year in painting a portion of the Society's apartments. A considerable portion still remains to be painted, either next year, or at some not very distant period.

Wbile on the subject of property, I should mention that Her Majesty has sanctioned "the continuance of the occupation of the Royal Observatory at Kew by the Royal Society," upon certain conditions, which have been accepted. The building will be devoted, as heretofore, to the use of the Kew Committee, whose work, it must be remembered, is provided for in the main by the Gassiot Fund.

Last year the Society accepied a portrait of Sir J. D. Hooker, painted by Mr. John Collier, at the request and at the expense of a considerable number of Fellows. I trust that the Society will approve the action of myself and a few others, in this year offering for our collection a portrait, by the same artist, of $\mathrm{Mr}$. Joule.

Mr. A. Le Gros has presented to the Society :a bronze medallion head, executed by himself, of the late Mr. Darwin.

The Library has received many valuable contributions both from our Fellows and from others. Among the latter I may mention the completion of "The Lepidoptera of Ceylon," from the Government of Ceylon; G. Retzius' "Gehörorgan der Wirbelthiere," from the author; a new edition of Abel's works, from the Norwegian Government ; and facsimile lithographs of some of the late Prof. Clifford's mathematical fragments, and the catalogue in two handsome volnmes from the Public Library of Victoria.

The printing of the general part of our library catalogue is in progress; and although, owing to unforeseen difficulties the hope expressed last year, that it would have been now finished, has not been fulfilled, yet there seems little doubt that early next year it may be in the hands of the Fellows.

On the completion of this work the Library Committee contemplate resuming another decade, $\mathrm{I}_{874.83}$, of the great Catalogue of Scientific papers; and the President and Council trust that the success which has attended the publication of the eight volumes already in existence will justify the Treasury in undertaking the printing of the second supplement when the MS. has been prepared.

In the staff of the Society I have happily no change to report. Of the existing members my own feelings would impel me to say much more; but, while they would probably; wish me to be silent, I trust they will pardon me in this one remark : that while recent ehanges make me less apprehensive of any future alterations, they at the same time make me hope that any alteration may be long postponed.

Although the number of papers presented to the Society during the past year, apart from their contents, does not convey any very important information, yet in continuation of past practice I may perhaps carry on the ten years' table. It is as follows, showing a slight diminution in the past year:-

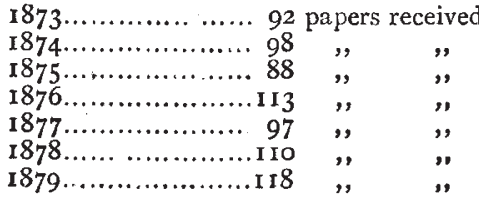


$1880 \ldots \ldots \ldots \ldots \ldots \ldots .123$ papers received.

1881 ................ ,

I $882 \ldots \ldots \ldots \ldots \ldots \ldots$...........,$"$,

Among the papers of this year, I may notice the elaborate research by Dr. Debus on "The Chemical Theory of Gunpowder," forming the Bakerian lecture ; the careful and longcontinued investigations by Professors Liveing and Dewar on the spectra of water, and of carbon, and of mixed vapours.

Nor must I omit mention of Dr. C. W. Siemens' bold and original theory of the conversation of the solar energy, which has already given rise to so much discussion. It will be sufficient for me here to say that upon the questions therein raised the last word has been by no means said ; and that, whether the theory be ultimately establishtd, or whether, like a phœnix, it shall hereafter give rise to some other outcome from its own ashes, it will ever be remembered as having set many active minds at work, and will always have a place in the history of -Solar Physics.

In Mathematics, definite integrals, and elliptic and the higher transcendents continue to occupy much attention, and in particular our "Transactions" contain an excellent contribution to the theta-functions of two variables, by Mr. Forsytb, of Liverpool. To the theory of invariants, Prof. Malet, of Cork, has given a happy extension in the direction of linear differential equations; but it is unnecessary to speak in detail of papers which either already are, or will shortly be, in the hands of the Fellows. I will only add that the "Philosophical Transactions" for 1882 will probably exceed in bulk, and not yield in interest to, those of any former year.

Looking outside the circle of our own publications, there has been one step gained during the past year, which, although in some sense a matter of detail, is really of great importance and interest. I allude to the paper by Lindemann, "Ueber die Zahl $\pi$ " ("Mathematische Annalen," Band xx, p. 213). It had long since been shown that both the numbers $\pi$ and $\pi^{2}$ are irrational ; but hitherto no proof existed of the impossibility of effecting the quadrature of the circle by means of the straight line and circle, and ruler and compasses. Regarded from an algebraical point of view, every such construction must depend upon the solution of a quadratic equation, or rather of a series of quadratics whereof the first has for its coefficients rational numbers, and the succeeding members of the series only such irrational numbers as occur in the solution of their predecessors. 'This being so, the final equation can always be transformed, by transposition of terms and squaring, into an equation of an even degree with rational coefficients. And, consequently, if it can be proved that $\pi$ cannot be the root of any algebraic equation whatever with rational coefficients, the impossibility of the quadrature of the circle will be thereby also proved. Starting from Hermite's researches ("Comptes Rendus," 1873), in which he established the transcendental nature of the number $e$, Lindemann has supplied the proof required with reference to the number $\pi$. It must be adnitted that the proof is neither very simple nor very easy to follow; and it remains only to be hoped that it may some day assume such a form as may influence the minds wich still exercise themselves upon the hopeless problem of squaring the circle.

A most important change in the relations ketween the Society and the Government in respect of State aid to science has been made this year. It will be in the recollection of the Fellows that an experiment was made for a period of five years, during which the sum of 4,000 l. was annually voted to the Science and Art Department, to be distributed at the recommendation of the Government Fund Commitee of the Royal Society. That experimental period terminated, as then mentioned in my address, last year. The grant to the Science and Art Department has been discontinued, and in the place of it an addition of $3,000 l$. per annum has been made to the Government grant, making $4, \mathrm{coOl}$. in all. In concluding this arrangement the following stipulations were agreed to. The increased grant is to be administered by a Committee identical with the late Government Fund Committee; a portion may be devoted to personal grants, subject, however, to special recommendations to the Treasury; and, lastly, unexpended balances may be carried forward from year to year, as bas hitherto been the case with the old government grant only. To the stipulation that the increased fund should be administered by the more extended committee the Society felt that no reasonable objection could be offered, because upon it the President and Council are represented in full, and the ex officio members are in the majority of cases Fellows of the Society. The object of the second stipulation was, so far as the Society is concerned, to secure at the outset for the personal grants the consent and support of the Treasury, and thereby to preclude the chance of objection being subsequently taken to any of our proposals under this head. The President and Council, however, recognising the importance of great caution in respect of personal grants, have of their own motion appointed a special sub-committee (in addition to the three previously existing), to which all personal applications recommended by any of the other sub-committees are specially referred, and without whose recommendation none can come before the General Committee. To the third mentioned point, viz., the power of retaining unexpended balances, the President and Council attach great value, because that power may enable the Committee to devote more of its funds than heretofore to some of the larger undertakings in scientific inquiry, leaving more of the smaller grants to the special funds already in existence in the hands of the Royal and other societies. The meetings of this Committee will probably take place twice a year, in May and November. In the present year it will not be possible to hold the second meeting before December, but there will be advantages in holding it hereafter in November, as the entire annual grants will then be made by the same Committee, and under the sanction of the same President and Council. In concluding these few remarks on the new arrangements, I cannot refrain from expressing my sense of the obligation under which the Society and Science at large are laid by the sympathetic and intelligent attention bestowed ucon the subject by the then Financial Secretary of the Treasury, the late Lord Frederick Cavendish.

Among other subjects referred to the Royal Society by Public Departments I may mention a reyuest from the Board of Trade for advice upon the question of improving the existing means at the Standard Office for the purpose of comparisons. At the request of the President and Council, Sir Ceorge Airy, Colonel A. Ross Clarke, and Prof. Stokes acted as a Committee, and drew up a very careful report, the value of which was fully recognised by the Board of Trade. The report suggested certain improvements in the present arrangements'; but, having reference to the duties of the Standard Office as defined by Act of Parliament, it was not considered necessary to insist upon extreme scientific accuracy, such, e.g., as that atrained by Colonel Clarke himself in his "Comparison of Standards" made at the Ordnance Survey Office at Southampton in 1866.

The arrangements for the observation of the Transit of Venus have been steadily progressing. The parties have now all started for their stations, after their period of training under the superintendence of Mr. Stone at Oxford. An adequate supply of instruments has been secured at moderate cost, and all the accessory parts have been procured and applied by the indefatigable care and forethought of our directing A stronomer.

The English Expeditions for the observation of the approaching Transit of Venus are-organized as follows :-

\section{ACCELERATED INGRESS}

Madagascar Observers. - Rev. S. J. Perry. Rev. W. Sidgreaves Mr. Carlisle.

Cape Observatory Observers.--Mr. Gill and Staff.

Aberdeen Road Observers. - Mr. Finlay, First Assistant of the Cape Observatory. Mr. Pett, Third Assistant of the Cape Observatory.

Montagu Roal Observers.-Mr. A. Marth, Mr. C. M. Stevens.

\section{RETARDED INGRESS.}

Bermuda Observers.-Mr. J. Plummer. Lieut. Neate, R.N. Capt- Washington, R.E.

Famaica Observers.-Dr. Copeland. Capt. Mackinlay, R.A. Mr. Maxwell Hall.

Barbadoes Observers. -Mr. C. G. Talmage. Lieut. Thomson, R.A.

Besides the observers at these stations, the Canadian Government has arranged to place three 6 -inch and some smaller telescopes in the field. Lieut. Gordon of Toronto was sent by the Canadian Government to England to make himself master of the proposed arrangements, and to secure the necessary instrumental equipment.

\section{ACCELERATED EGRESS.}

The stations for Retarded Ingress are also ivailable for Accelerated Egress. 


\section{RETARDED EgRESS.}

Brisbane Observers.-Capt. W. G. Morris, R.E. Lieut. H. Darwin, R.E. Mr. Peek.

New Zealand Observers.-Lieut.-Col. Tupman, R.M.A. Lieut. Coke, R.N.

Besides these observers sent specially from England, the Observatories at Melbourne and Sydney are most favourably situated for observing the Egress. The Directors of these Observatories, Mr. Ellery and Mr. Russell, have promised their co-operation, and their Governments have placed funds at their disposal to cover any necessary expenses.

Unless unfavourable weather should prevent the transit being seen at some of the stations, we may expect some nine or ten pairs of corresponding observations, both at Ingress and Egress, from the British expeditions alone. These observations are certain to be largely supplemented by those made by the observers of other nations ; and it is hoped, from close agreement between the instructions issued to the different observers, that the whole may ultimately be available for combination in one general discussion.

The American astronomers, encouraged by the partial success which attended the plan they adopted in 1874 , are relying chiefly upon the photographic method; they have sent expeditions to South America and the Cape of Good Hope.

Austria does not take any active part in observing the Transit.

France sends out eight well equipped expeditions, full particulars of which have been published in the "Comptes Rendus" for October 2.

From Holland no special expedition will be sent out, but Lieutenent Heyminx, of the Dutch Navy, will observe the transit in the West Indies, probably at Curaçoa.

Italy will confine its operations to observatories in that country.

Russia, also, has decided to send out no expeditions of its own, but it has aided the efforts of other countries by lending a $6 \cdot 5$-inch reflector to the Danish Government, and has placed two excellent $4^{*} 3$-inch heliometers in the hands of the French astronomers, MM. Tisserand and Perrotin. The considerations which led the Russian Government to this conclusion have been explained in the following paragraphs of a letter from $\mathrm{Mr}$. Struve to myself :

"Experience since 1874 has sufficiently proved that there is no prospect whatever, even with combined international efforts, of obtaining by the present transit a geometrical determination of the parallax of the sun, which would not soon be surpassed in accuracy by other recent methods (for example, that suggested by Mr. (Gill), methods which are capable of being repeatedly employed, and that without any costly expeditions.

"Further, although it must be admitted that so rare an opportunity of studying the atmosphere of the planet ought not to be neglected, yet it seems certain that so many and such excellent data will be obtained through the agency of the United States, as well as by other countries having well provided observaturies in the southern hemisphere, as well as by other seafaring nations." Under these circumstances Russia has not considered it incumbent on itself to organise any observing parties.

Spain has sent two parties of naval officers, well equipped with 6 -inch equatoreals and other instruments, to the Havana and Porto Rico.

Last year I expressed a hope that the difference of longitude between Singapore and Port Darwin in Au tralia would be determined by Commander Green of the United States' Navy in concert with $\mathrm{Mr}$. Todd. This operation, however, in consequence of some incorrect information furnished to Commander Green as to the intentions of our home authorities in the matter, was not carried out. After various proposals, extending over a period of not less than two years, I am happy to say that it now appears likely that the work will be performed. Through the liberality of the Secretary of State for War an extension of leave has been granted to Lieutenant Darwin, who accompanies Captain Morris to Brisbane to observe the transit of Venus, enabling him to undertake the work. He has received instructions to arrange with $\mathrm{Mr}$. Todd all details of the operation. The publication of the results obtained by Oudemans and Pogson for the difference of Ionoitude between Madras and Singapore has now left only one link wanting, namely, that between Batavia and Port Darwin, to connect Australia with English longitudes. Lieutenant Darwin is eminently qualified for the work; and it seem ; a happy coincidence that it should fall to his lot to connect astronomically the distant port named after his father with the furtherest ascertained point in that direction. I should not omit to add that Mr. Todd has placed all the telegraphic appliances under his command at the disposal of this service, and it is to be hoped that the determination will prove as useful to the Australian coloniesias it will be valuable for the purposes of the transit. The best thanks of the Committee have already been given, but I am glad here publicly to recognise the valuable assistance rendered to the Committee in these long negotiations by the Great Eastern Telegraph Company.

Iu the course of last year the Treasury made known to the Society that in conseqnence of Sir Wyville Thomson's ill health, their Lordships proposed that his chief assistant, Mr. Murray, should undertake the general editorship of the Reports of the Challenger Expedition ; so that Sir Wyville might devote himself more exclusively to the personal narrative. At the request of their Lordships a small Committee, with whom Mr. Murray might consult from time to time, was appointed, consisting of the President and Officers, Sir Joseph Hooker and Prof. Huxley; but before the Committee could meet the lamentable death of Sir Wyville Thomson occurred. They met, however, shortly afterwards, and having added Prof. Mosely to their number, they received from $\mathrm{Mr}$. Murray, who attended, a detailed statement of the existing condition of the whole arrangements conected with the Report. From this statement it appeared that, in addition to the original estimate of $20,000 l$. given by Sir Wyville Thomson, the work actually in progress and entrusted to the several authors required a further sum of about $20,000 l$., and that if the series should be completed, by describing on the same scale groups as yet unallotted, an additional expense of about $6,000 \%$. would be entailed. In forwarding this statement to the Treasury, the Committee stated that, in their opinion, $\mathrm{Mr}$. Murray's estimates were drawn up with great care and judgment, and that in view of the remaining Reports being carried out on the same scale as those already published, they were reasonable and sound. As to the cause of the great discrepancy the Committee felt themselves unable to offer any explanation; the conduct of the whole business having been left in Sir Wyville's hands, without reference to the Society. They further were of opinion that Mr. Murray might safely be entrusted, under the control and supervision of the Committee, with the entire future management of the undertaking.

After some further correspondence it was suggested that $\mathrm{Mr}$. Murray should furnish the Committee with a statement of the existing condition of the Reports and their management, which should form a starting point for the responsibility of the Committee; and that he should keep the Committee well informed from time to time of the progress of the undertaking. These su rgestions were cordially accepted bp their Lordships, and with the general statement whieh Mr. Murray submitted in October, the special duties and responsibilities of the Committee have begun.

Since last year, three more volumes ef the Report have been published, making six in all. The new volumes form volume iv, and v, of the Zoology, and volume ii. of the Narrative. The latter volume comprises the magnetic results, the meteorological observations, the report on the pressure errors of the thermometers, and the petrologyiof St. Paul's rocks. Vol. i. of this section, containing the narrative proper, is partly in type; and will, it is hoped, be issued during the summer of 1883 . Other volumes will als $)$ appear from time to time.

In connection with this subject, I may mention that the collection of specimens from the Challenger Expedition are being received at the British Museum, as the particular portions are released by the progress of the publication of the Report. Those derived from the Alert Expedition to the South Pacific Ocean, have been deposited in the Museum by the Admiralty, and are now being arranged and described. Dr. Günther hopes to be able to produce a printed descriptive catalogue of the collection before the expiration of the present year. And I desire here to acknowledge the service rendered to science by the Admiralty in commissioning Dr. Coppinger to accompany that expedition for scientific purposes.

I an indebted to $\mathrm{Mr}$. Murray for the following interesting account of a cruise made last summer to complete some part of the Challenger work.

H.M.S. Triton was engaged, from the $4^{\text {th }}$ of August to the 4th of September, in a re-examination of the physical and biolorical conditions of the Faroe Channel.

The chief objects of the cruise were to ascertain by actual 
soundings, the character of a ridge running from the north of Scotland to the Faroe fishing banks, an i separating, at depths exceeding 300 fathoms, the cold Arctic water with a temperature about $32^{\circ}$ from the so-called Gulf Stream water on the Atlantic side with a temperature of $47^{\circ} \mathrm{F}$. This ridge was traced in considerable detail by means of cross soundings directly across the channel, and the top was found to be on an average about 260 fathoms, beneath the surface. In the northern half of the ridge, however, a small saddle-back was found with a depth of a little over 300 fathoms, through which some of the Arctic water seemed to flow and to spread itself over the bottom on the Atlantic side of the ridge. The top of the ridge is entirely composed of gravel and stones, but mud and clay are found on either side at depths exceeding 300 fathoms. Many of the stones are rounded, and some of them have distinct glacial markings. They are fragments of sandstone, diorite, mica-schist, gneiss, amphibolite, chloritic rock, micaceous sandstone, limestone, and other minerals. The ocean currents here appear to be strong enough, at a depth of between 250 and 300 fathoms, to prevent any fine deposit, such as mud or clay, being formed on the top of the ridge. All the indications obtained of the nature of this ridge, seem to imply that it may be a huge (terminal ?) moraine.

It is worthy of notice that the "Wyville Thomson Ridge' is only a little to the east of the position marked out by Croll from the observations of Geikie, Peach, and others, as the probable limit of the perpendicular ice cliff formed in North Western Europe during the period of maximum glaciation.

The dredging captures show the same ruarked difference as had previously been pointed out in the fauna of the two areas; those in the cold area being of a distinctly Arctic character, and those in the warm area resembling the universally distributed deep-sea fauna of the great oceans. A fair proportion of new species were also found.

The last trip of the Triton took place from Oban, on the I Ith September, to the deep water in the Atlantic westward of Ireland. The object of this trip was to get directly a determination of the pressure unit of the guages employed in testing the Challenger thermometers. The original determinations were made indirectly' by the help of Amagat's results as to compression of air. The observations taken are not yet reduced, but several successful trials were made at depths of 500,800 , and 1,400 fathoms.

\section{(To be continued.)}

\section{MIKLUKHO-MACLAY ON NEW GUINEA}

$\mathrm{O}^{\mathrm{N}}$ October II M. Miklukho-Maclay gave, at the Russian Geographical Society, the first of a series of lectures on his sojourn in New Guinea. These lectures have attracted great audiences. His remarkable collections of household articles and implements of Papuans and of various tribes of the Malacca Peninsula, and the many drawings reproducing scenes of the life, dwellings, graves, anthropological types, \&c., of the natives, are exhibited in the rooms of the Geographical Society, and attract many visitors.

M. Miklukho-Maclay left St. Petersburg in 1872, and went on board a Russian ship to New Guinea. He expressed the wish to be left there for at least a year, and it was fifteen months after his being landed that he was taken up by a ship which brought him to Batavia. His stay in New Guinea was beset with diffculties. He lived in a small hut, was short of provisions, which he had to supply by hunting, and his health was quite broken down. But he entered into very close relations with the natives. In Batavia he stayed for several years, and published (in German) the results of his anthropological and ethnological observations among the Papuans, on the Brachycephaly of the same, and on the climate of the "Maclay-coast" in the Batavian scientific journal, Natuurkundig Tijdschrift voor Nederlandsch Indie. A paper (in French) on the Vestiges of Art among the Papuans appeared in the Bulletin de la Société d'Anthropologie de Paris for 1878 . In 1876 he undertook a new journey on board the English schooner Sea Bird, and visited the Yap, Pelau, Admiraity, and Ninigo Islands, and went again to the coast of New Guinea, to which his name is now attached. An account of this journey has appeared in the Lzvestia of the Russian Geographical Society and in Petermann's Mittheilungen for 1879. During this second sojourn in New Guinea M. MiklukhoMaclay was lodged more comfortably, and was enabled to pursue scientific investigations (anthropological measurements and anatomical researches) with less difficulty. He also explored in a canoe, with natives, the coast of New Guinea between Cape Croaz and Cape Teliata. Having undertaken his adventurous journey on his own account with but a little occasional support from the Geographical Society, M. Miklukho-Maclay was often in difficult circumstances; but a few years ago a public subscription was opened by the Russian papers, and the Russian Society immediately came to his aid, thus enabling him to continue his researches.

When in search of a place at which to study the customs and life of the primitive people at the lowest stage of culture, $\mathbf{M}$. Maclay chose the north-western coast of New Guinea, close by Astrolabe Bay, which was never visited before by Europeans. Neither Dampier nor Dumont D'Urville, who both passed close by, had landed there. He built his hut between two Papuan villages, on a promontory that was occupied by nobody. At the beginning the Papuans wished him to go back whence he came, and obstinately showed him the sea; sometimes they launched their arrows close by him, but without wounding. By great endurance however, by his good nature, and especially by a continuous self-control and severe watching over his own actions, M. Maclay soon won the confidence of the natives. He always strictly kept his word, even in the most insignificant circum. stances, and therefore had afterwards the satisfaction of hearing the natives saying "Balan Maclay hoodi" ("The word of Maclay is one "). The natives used to call him Kaaram-tamo, "The Moonman," partly on account of the supernatural capacities they ascribed to him, and partly on account of his having once, when searching for something about his hut in the night, lighted a white signal-fire that was left from the ship which brought him. The first visits of M. Maclay to the Papuan villages were a source of great trouble among the natives; the women were concealed and the men seized their arms. $M$. Maclay used then to announce beforehand his arrival by loud whistling, and the natives concluded he did not wish to do them harm. By and by he won the confidence of the natives to such an extent that an attack of a hostile tribe having been expected, his neighbours brought their women and children to his hut, to be under his protection. The war was thus prevented, and the authority of the "Moon-man" was sufficient to prevent further wars.

The natives of this coast are at the lowest stage of culture. Before M. Maclay's arrival they did not know the use of metals, all their implements being made of stone, bones, and wood. They did not even know how to make fire. If the fire were extinguished in a hut, it was taken from another; it would be taken from a neighbouring village if extinguished in all the huts of the village at once. 'Their grandfathers told them of a time when they had no fire; then they ate their food quite raw, and a disease of the gums spread among them. They do not bury their dead. The dead are put in a sitting position, the corpse is covered with leaves of the cocoa-palm, and the wife must keep a fire close by him for two or three weeks, until the corpse is dried. Corpses are buried only if there is nobody to keep the fire.

M. Maclay left the Papuans with regret, when a passing schooner took him, in 1878 , to Singapore. He expects for his friends the fate of the inhabitants of the Melanesian Archipelago, where the population rapidly diminishes on account of the "kidnapping" of men and women to sell them into slavery, which is practised to a great extent by crews of ships of all nationalities of the civilised world.

In his second lecture, M. Miklukho Maclay gave further information with regard to the Papuans of New Guinea. Previous anthropologists had admitted the existence of at least two different races in New Guinea, and had made a distinction between the Papuans inhabiting the coast and those of the interior. After several visits to New Guinea, as well to the coast, as to the interior, M. Maclay came to the conclusion that this supposition is not correct. 'The Papuans of the interior belong to the same race as those of the coast, and there is throughout New Guinea but one single Papuan race. Virchow found it alsu necessary, on the ground of craniological measurements, to distinguish the Papuans from the Negritos of the Philippine I lands, and to admit that the former are dolichocephalic, and the second brachiocephalic. Hundreds of measurements made by M. Maclay brought him to the conclusion that both types have their representatives even among the purest Papuans of the Maclay coast, and that the transversal diameter of the skulls of Papuans varies everywhere within so wide limits ( 62 to 86 per cent. of the length of the skull), that no classification can rest on this feature. It was stated also that a special 